\title{
Fam. Anatide.
}

\section{Dendrocygna arcuata (Cuv.).}

This small Duck is very common here on the marshes. They are very wild and difficult to shoot, but excellent eating. Taken young, they become very tame, and breed in confinement, freely associating with other poultry; but they are excessively pugnacious, and tyrannize even over the geese.

\section{Fam. Laride.}

\section{Gelochelidon anglica (Mont.). (Simbangan.)}

Of course a sea-bird, though shot in a freshwater marsh, where I had observed it some days flying over the water like a Swallow.

\section{Sternula minuta (Linn.).}

Procured in the same placc.

\section{June 9th, 1863.}

\section{John Gould, Esq., F.R.S., in the Chair.}

Dr. Sclater made some observations on some of the interesting species of animals he had seen during a visit he had just paid to the Zoological Gardens of Amsterdam, Rotterdam, and Antwerp. Amongst other species not yet received in this Society's collection, but of which examples were exhibited in the sister establishments, he called particular attention to

1. Cervus equinus - the Bornean Deer of the Rusine type, of which several specimens were in the Amsterdam Gardens, and which appeared readily distinguishable from the Cervus rusa of Java by its darker colour, shorter hair, and the stouter antlers of the male.

2. Cervus kuhlii-the smallest species of the same section of the genus, from the Bavian Islands.

The Amsterdam Society now possessed both sexes of this little Deer, which was breeding with them readily. It resembled in size and general appearance Cervus porcinus of India, but was absolutely without spots, even in its youngest stage, and easily distinguishable in other ways.

3. Cervus nemorivagus of Surinam, of which he had succeeded in obtaining a pair from Mr. Westerman for the Society's Menagerie.

4. Lagostomus trichodactylus, a well-known American Rodent from the Pampas, of which he had seen a living example for the first time in Amsterdam.

5. Cathartes urubitinga, Natt. MS. (v. Pelz. Sitz. Wien. Ak. 

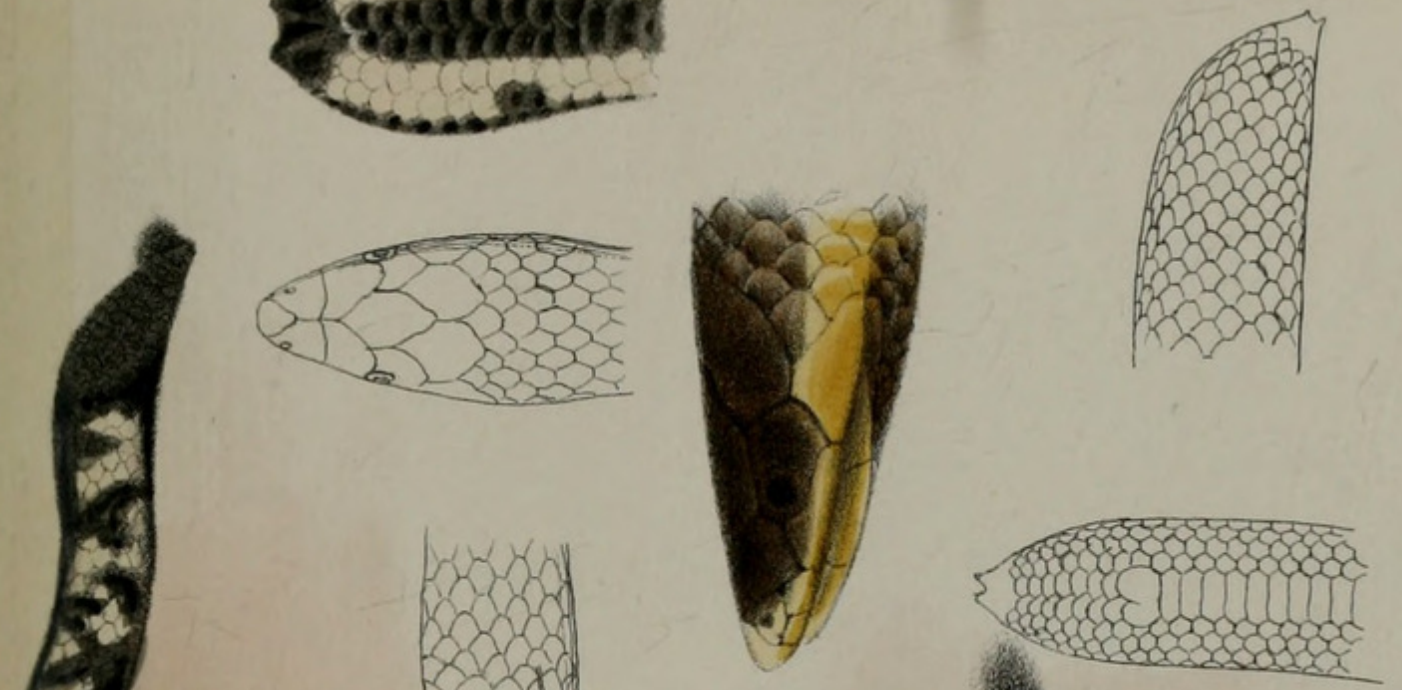

0
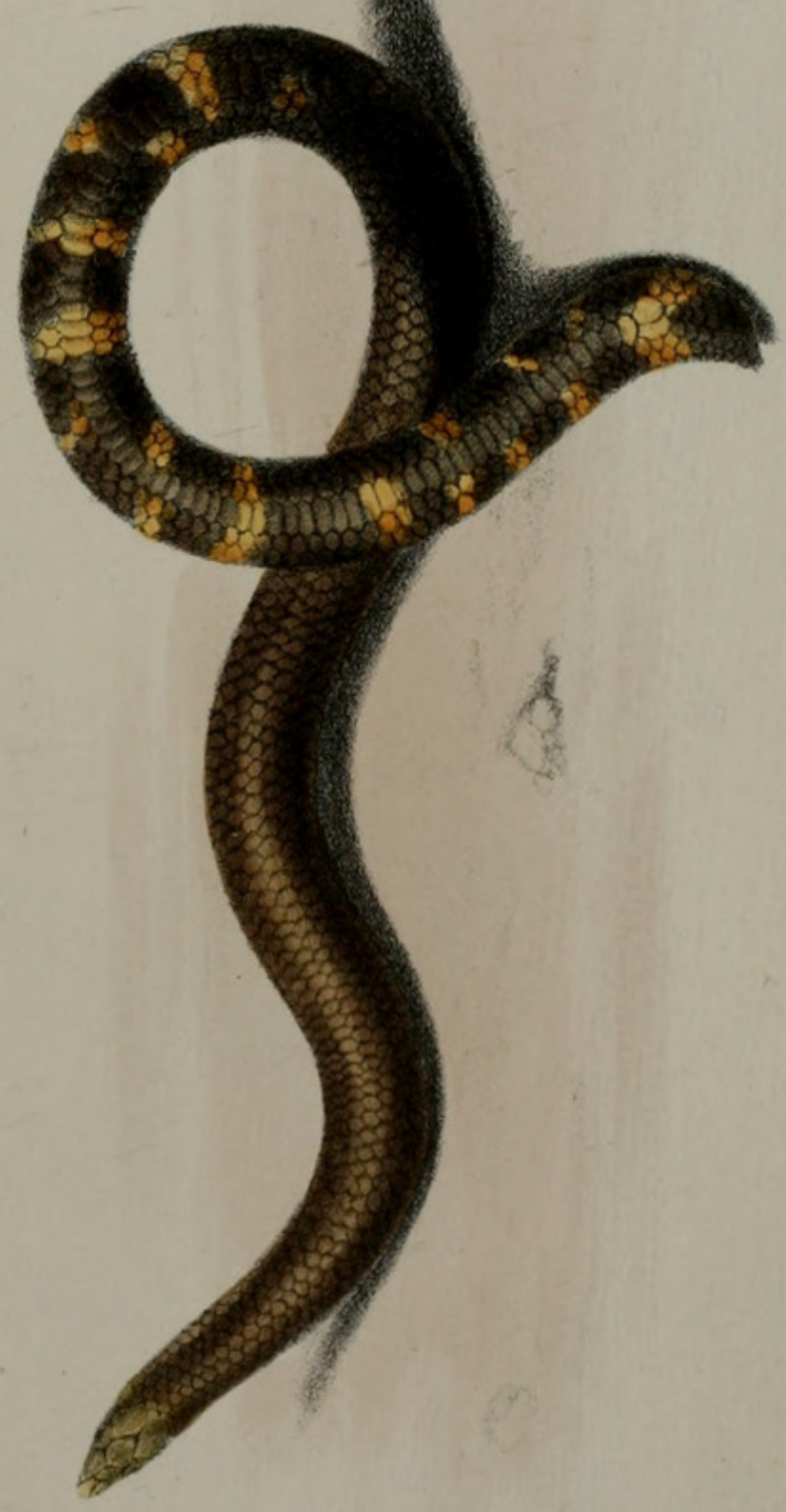

$N$ 



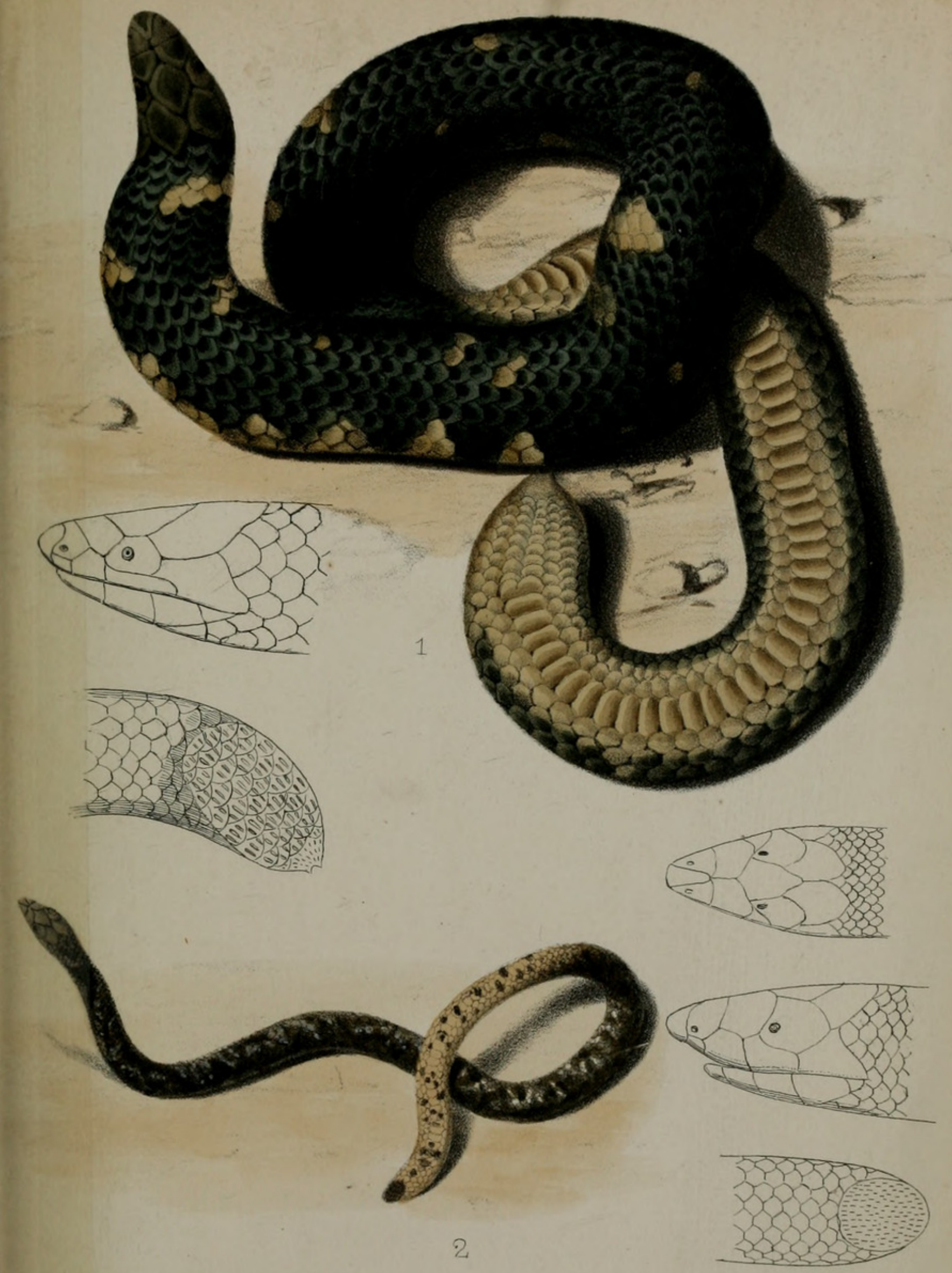

Jury lith

M.\&N Hanhart 



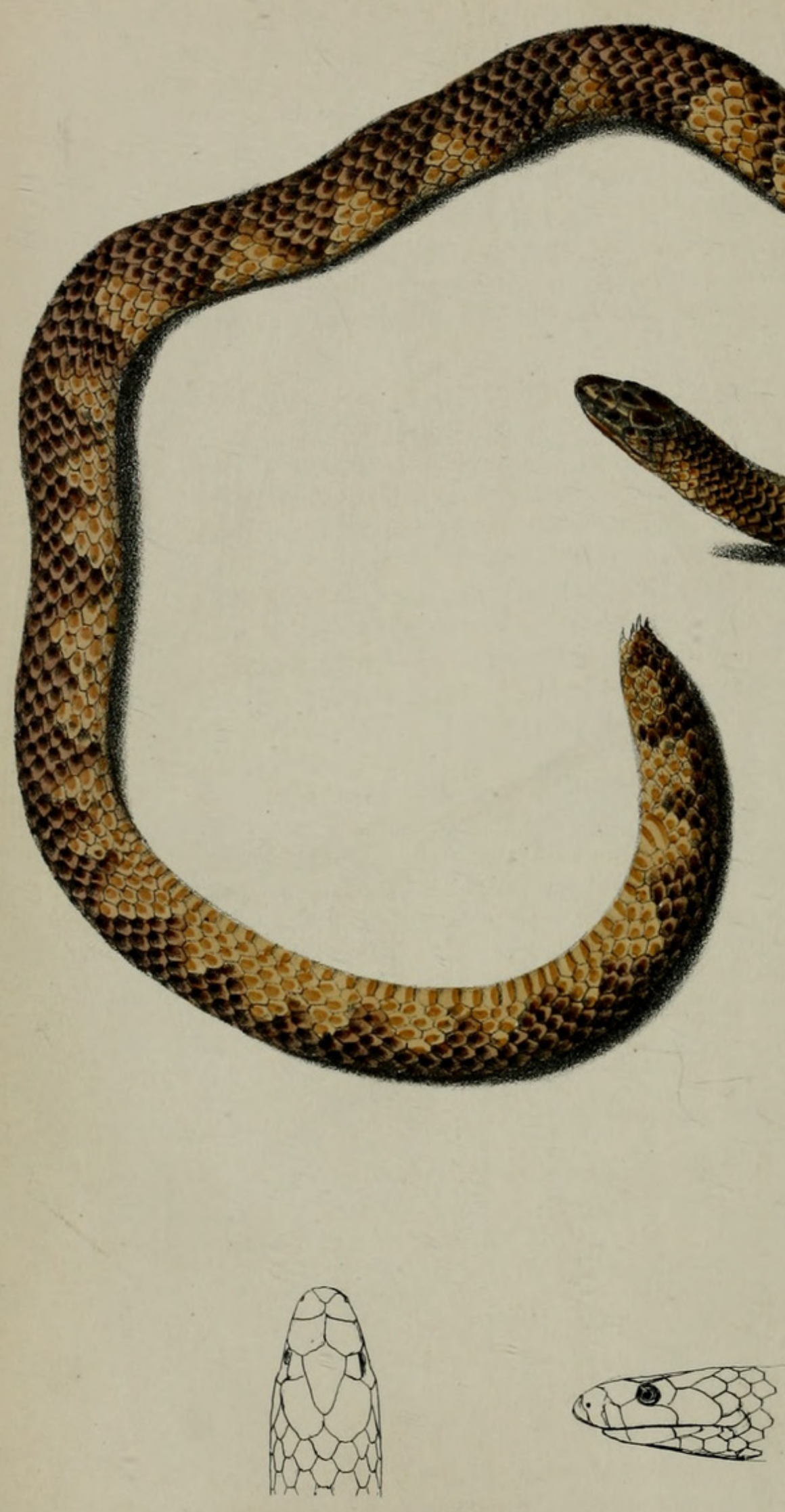
1861 , p. 7 ), a species very distinct from the Red-headed $C$. aura, being smaller in size, and having the naked skin on the head yellow -from Surinam, where the true C. aura was also found, specimens of both these species from that country being exhibited side by side in the Zoological Gardens at Amsterdam.

6. Leptoptilus capillatus (Temm.), a fine species of Adjutant from Java in the Amsterdam Gardens.

7. Casuarius uniappendiculatus, Blyth.-The example of this species, already spoken of at previous meetings of this Society*, was still living in fine adult plumage in the Amsterdam Society's Gardens.

8. Felis aurata (Temm.).-A specimen of this scarce and beautiful Sumatran Cat was in the Zoological Gardens at Rotterdam.

9. Cervus schomburgki, Blyth, P. Z. S. 1863, p. 155.-A Deer lately received by $\mathrm{Mr}$. P. Martin, Director of the Amsterdam Gardens, from Siam, was perhaps the female of this new species of Mr. Blyth. Mr. Martin was making efforts to obtain the male.

10. Tantalus ibis.-A bird of this scarce species had been living for some years in the Antwerp Gardens. Dr. Sclater called attention to the fact that an individual of the same species in immature plumage had just been added to the Society's collection.

Mr. W. Williams of Tregullow communicated some observations upon the growth of the young West Indian Tortoises hatched in this country, as mentioned in the Society's 'Proceedings' for 1862 (page 266). The larger of the two young Tortoises on the 21 st of May weighed nearly an ounce, and was about $4 \frac{3}{8}$ inches in girth round the middle. The smaller of the two weighed exactly $\frac{3}{4}$ of an ounce, and measured about 4 inches in girth. The heat of the pinepit in which they had been kept had varied from $65^{\circ}$ to $70^{\circ} \mathrm{Fahr}$. during the winter; as the spring advanced, the heat had ranged from $75^{\circ}$ to $85^{\circ}$.

The following papers were read:-

1. Descriptions of New Species of the Family Uropeltide From Southern India, with Notes on other littleKnown Species. By Captain R. H. Beddome, Officiating Conservator of Forests, Madras.

(Plates XXV., XXVI., XXVII.)

Genus Silybura.

1. Silybura shortil. (Pl. XXV. fig. 1.)

Head-plates as in S. brevis, but vertical, 6 -sided, and occipitals pointed behind ; caudal disk very large and well-defined; scales very

* See Trans. Zool. Soc. iv. p. 359.

Proc. Zool. Soc.-1863, No. XV. 
strongly 2-3-keeled; terminal scale large, slightly bicuspid. Scales of the body in 17 rows, on the neck in 19. Eye very large. Total length 9 inches. Colour blackish, with large dull yellowish white mottlings (the two colours nearly equally divided); tail beneath black, with a yellowish band on each side. Abdominals 134 ; subcaudals 10 .

Shevaroy Hills (4500 feet elevation). Forwarded to me by Dr. Short.

\section{Silybura ocellata.}

Rostral pointed and much produced; nasal scutella meeting behind the rostral, and separating it from the frontals; eye very small, obscure, in front of ocular shield; other shields and labials as in the genus; scales round the neck in 18 rows, round the trunk in 17 ; caudal disk not very clearly defined; scales 2-5-keeled; terminal shield entire, or slightly 2-3-pronged; abdominals 199 ; subcaudals 8 or 10 pairs, some generally entire. Total length $14 \frac{1}{2}$ inches. Colour of the body of the male yellowish, becoming gradually brown near the head and tail, of the female dull brownish, of the young dark purplish brown; all banded with transverse rows of four or five black-edged white or yellow spots (like eyes), generally rather irregularly placed. Sides of the belly with transverse, very irregularshaped, yellow or white blotches, rarely meeting over the abdominals, and forming a transverse band.

Walaghat, on the western slopes of the Nilgherries, at an elevation of 3500 feet, in the dense moist forests. I procured three specimens-male, female, and young.

3. Silybura brevis, Günther.

The specimen here figured only differs from the one described by Dr. Günther in having sixteen rows of scales instead of seventeen, and in the terminal scale of the tail being entire and not bicuspid.

I procured this specimen on the Nilgherries; the one described by Dr. Günther was found on the Anamallays.

\section{Sitybura nilgherriensis. (Pl. XXVI. fig. 1. )}

Scales in 17 rows; anal large, bifid; subcaudals 9 ; snout obtuse : rostral far produced back between the nasals ; nasals just meeting behind the rostral; vertical 6 -sided, pointed in front and behind; eye rather large, in front of ocular shield; caudal disk well defined: scales very prominently $2-3$-keeled; terminal scale ending in two points. Colour of the body of an indigo-hue, with small dull yellow blotches; belly dull yellowish. Length 17 inches; circumference 3 inches.

Ootacamund, Nilgherries, 7000 feet elevation.

This is by far the largest Earth-snake we have in Southern India.

It is possible that $S$. brevis may be the young of this species : they are, however, found at different elevations; and without intermediate forms I cannot venture to unite them, that being the smallest Earthsnake in our presidency, and this the largest. There is, however, 
scarcely any difference in the shields of the head, though the head of Silybura brevis is broader.

\section{Silybura beddomir, Günther.}

I have lately procured numerous specimens of this Snake on the Shevaroys, elevation 4500 feet. I have also found it in the Mudumallay Forest, elevation 3000 feet. The spots on the scales are yellow, turning white in spirits.

Note.-Silybura brevis, nilgherriensis, shortii, and macrolepis (a Ceylouese species) have a well-defined head, with broad snout and a large eye. Silyburce ellioti, beddomii, and ocellata have a pointed snout and a small eye (as in the genus Rhinophis).

\section{Rhinophis SANGUineus.}

Scales of the body large, in 15 rows; of the anterior portion of the trunk sometimes in 17; rostral much produced, very sharp, conical, horny, produced back, and covering the conjunction of the nasals; nostril in front of nasal shield; eye very small and obscure, in front of ocular shield; four upper labials, 1st small, 2nd, 3rd, and 4th large; caudal disk nearly as long as tail, oblong, covered with excrescences, a red streak down the centre and one on each side. Colour of the body bluish black; belly bright red, with blackish mottlings; anal bifid; subcaudals of the male 9 or 10 pairs, each with 4 to 6 keels, and some of the approximated ventral plates and a few of the two lowest rows of scales also keeled; female subcaudals 6 or 7 . Total length of large male 13 inches, female 10 inches; circumference 1 inch; abdominals 195 .

The brilliant red colour of the abdomen fades in spirits.

I procured numerous specimens of this species at Cherambòdy in the Wynand (Malabar), elevation 3500 feet; they were all dug up in one spot. I have not met with it elsewhere.

\section{Rhinophis microlepis. (Pl. XXVI. fig. 2.)}

Scales of the body small, in 15 rows; of the anterior portion of the trunk in 17, of the neck in 19. Caudal disk oblong, orbicular, onehalf the length of the tail, covered with excrescences, which are confluent into streaks; subcaudals 10 ; anal bifid; head-plates as in $R$. sanguineus, but rostral less sharp. Colour of the body greyish black, with indistinct dull yellowish white mottlings ; belly yellowish white, with dark mottlings; tail beneath yellowish, with a broad black spot. Abdominals very small, 199. Total length 6 inches; circumference $6 \frac{1}{2}$ lines.

I procured this (a solitary specimen) in the Wynand, elevation 3500 feet.

\section{Genus Plectru rus.}

* Eye rather large, with a supraorbital shield.

8. Plectrurus perrotteti, Gray, P. Z. S. 1858,p. 265.

This is most abundant on the tops of the Nilgherries, 7000 to 
8000 feet; it is dug up in gardens, and found under the turf and under stones. My largest specimen is 14 inches long; it rarely, however, attains that size : the one figured is the usual size of the adult.

\section{Plectrurus guentheri. (Pl. XXViI.)}

Scales of the neck in 17 rows; anterior portion of the trunk in 13 rows, of the rest of the body in 15 rows; head-shields as in $P$. perrotteti, only the rostral is not produced so far back. All the seales of the tail 5-6-keeled, and some of the approximated scales of the body also keeled; terminal scale of the tail with four sharp points, and covered with small tubercles; abdominals 172 , and a bifid anal ; subcaudals 12 . Total length 13 inches, circumference $1 \frac{3}{8}$ inch. Colour of the body of a bright reddish purple; belly yellow, the yellow colour rising up on the sides of the trunk into regular pyramidshaped markings, and the purple colour descending in the same way down to the abdominals.

I procured this very fine species in the moist forests at Walaghat, on the western slopes of the Nilgherries ( 3500 feet elevation). I have great pleasure in naming it after Dr. Günther.

$$
\text { ** Eye small, no supraorbital shield. }
$$

\section{Plectrurus wynandensis.}

Scales round the body 15 , round the neck 16 or 17 ; rostral scarcely produced back between the nasals; no supraorbital; muzzle more obtuse than in P. perrotteti; eye small; subcaudals 11 pairs; anal large, bifid; tail compressed; scales smooth, terminal spinose, tail ending in a single horny point. Colour bluish black, with broad white blotches on the belly, which become larger and more numerous towards the tail; tail uniform bluish black.

Wynand, elevation 3500 feet.

\section{Plectrurus pulneyensis. (Pl. XXV. fig. 2.)}

Rostral rather obtuse, produced back between the nasals, and touching the frontals, nasals not meeting; eye small, in front of the ocular shield ; no supraorbitals; vertical 6 -sided; occipitals rounded behind; 4 upper labials. Scales round the neck 19, round the body 17 ; subcaudals, male, about 12 , female $6-8$. Tail compressed, ending in a small spinose keel, more or less bicuspid. Scales of the tail all smooth. Colour uniform earthy brown; a lateral bright yellow streak from the labials continued on each side of the trunk, about 1 inch or $1 \frac{1}{2}$ inch in length; a few minute yellow specks on the back ; belly with broad bright yellow transverse bands, very irregular as to number and shape; yellow markings about the vent and tail.

Very abundant on the Pulney Hills, 7000 to 8000 feet, where it takes the place of $P$. perrotteti of the Nilgherries; in habits, \&c. exactly the same as $\boldsymbol{P}$. perrotteti.

The very brilliant yellow fades in spirits. 
These last two species differ from the typical form of this genus in their much smaller size and in the absence of a supraorbital shield. As, however, they have the same compressed tail, I prefer keeping them in this genus to making a new genus for them.

\section{ON a Species of Vipera hitherto unknown. \\ By E. D. Cope.}

\section{Vipera confluenta, sp. nov.}

Head much longer than broad, covered with small scales, which are more or less keeled as far anterior as the postfrontal region. Superciliaries little developed, once or many times divided. Scales of the upper surface of the muzzle larger; a well-developed supranasal. Prenasal large, erect, undivided; postnasal developed in front of, and narrowly superior to, the nostril. Three rows of scales between the orbits and the superior labials. The latter are elêven in number, the fourth longest, the first in contact with the prenasal. Rostral higher than broad. Inferior labials fourteen, fifth largest. Scales of the body in 25 rows, all keeled, never spiniferous. Gastrosteges 180 ; urosteges 48 . Length from muzzle to rictus $1 \frac{1}{4}$ inch, from muzzle to vent $30 \frac{1}{2}$ inches, from vent to end of tail $4 \frac{2}{3}$ inches.

General ground-colour brownish yellow; belly paler. A broad undulating brown band, resembling a confluence of alternate rounded spots, extends from the nape to the end of the tail. A dark brown lateral streak, which is interrupted at regular intervals, extends
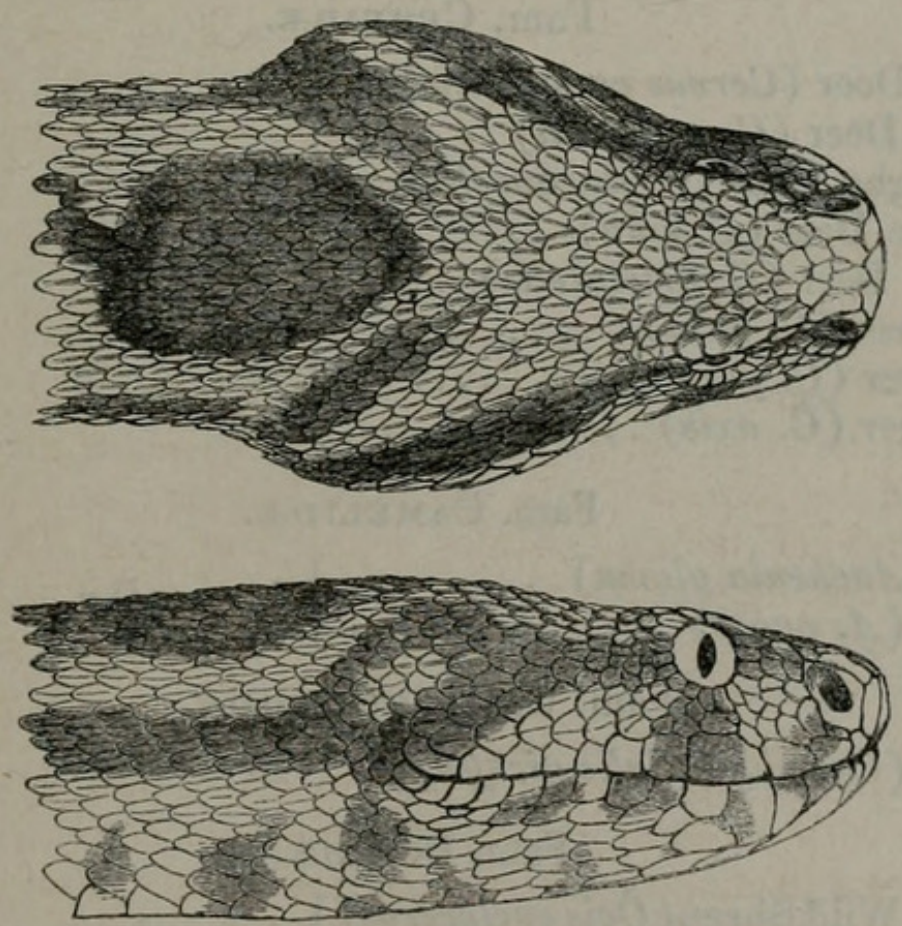

throughout the greater part of the length. Labial regions yellowish; a brown band from orbit to angle of mouth; a brown spot below orbit. 
The habitat of this species is not known, but is probably Africa. Its nearest ally is the $V$.libitina, with which it forms a section of the genus characterized by a superciliary plate more or less subdivided, and leading off to Echidna. In the writer's opinion, the genus Vipera is to be separated from Echidna by its large prenasal plate, and postnasal slightly developed above the nostril, which is always lateral : in Echidna the prenasal is replaced by scales, and the postnasal is much developed above the nostril, which is usually vertical ; in $E$. atropus the nostril is vertico-lateral.

One specimen of this Vipera belongs to the Academy of Natural Sciences of Philadelphia, and another is in the British Museum. For an opportunity of examining and figuring the latter, my acknowledgments are due to the distinguished officers of the institution, Drs. Gray and Günther.

3. Record of the Period of Gestation of certain Ruminants which breed in the Society's Gardens. By $P$. L. Sclater, M.A., Ph.D., F.R.S., etc., Secretary to the Society.

The period of gestation of certain animals of the class of Ruminants which habitually breed in the Society's Menagerie has been ascertained with tolerable exactness. Of course the period is slightly variable; but the times given in the following list are, on the average, very faithfully adhered to.

\section{Fam. Cervide.}

Wapiti Deer (Cervus canadensis). . Persian Deer (C. wallichii) ....... Barasingha Deer (C. duvaucelii)... Japanese Deer (C. sika) ......... Sambur Deer (C. aristotelis) .... Rusa Deer (C. rusa)............. Hog Deer (C. porcinus) $\ldots \ldots \ldots$ Axis Deer (C. axis)

Fam. Camelide.

$\left.\begin{array}{l}\text { Lama }(\text { Auchenia glama }) \ldots \ldots \ldots \\ \text { Alpaca }(\text { A. pacos }) \ldots \ldots \ldots \ldots\end{array}\right\} 11$ months.

Fam. Camelopardide.

Gìraffe (Camelopardalis giraffa) .. 15 months.

Fam. Bovide.

Punjab Wild Sheep(Ovis cycloceros) 4 months. Moufflon Sheep (O. musimon)..... 3 months. Leucoryx Antelope (Oryx leucoryx) 8 months. Eland Antelope (Oreas canna) .. 9 months. Nylghai Antelope (Portax picta). Between 8 and 9 months. 
साSH MUSEO

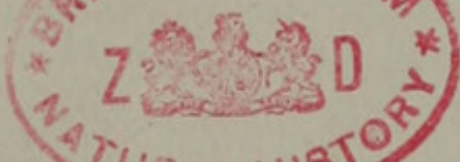

YURAL HIST 


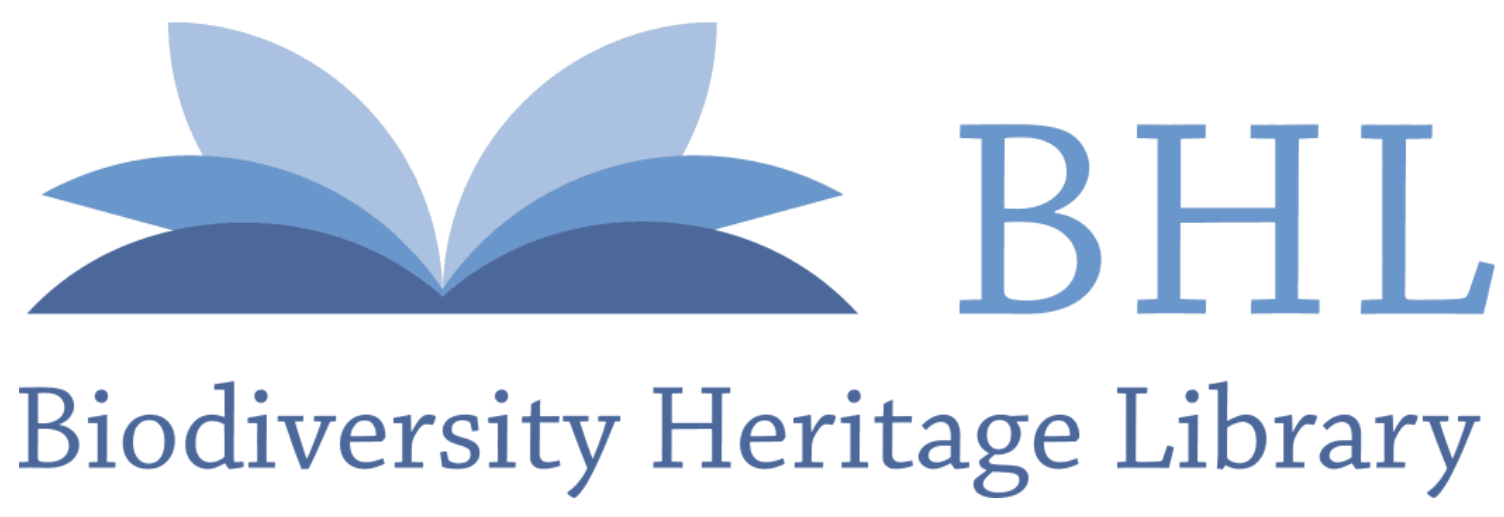

Gould, John. 1863. "June 9th, 1863." Proceedings of the Zoological Society of London 1863, 224-237. https://doi.org/10.1111/j.1469-7998.1863.tb00392.x.

View This Item Online: $\underline{\text { https://www.biodiversitylibrary.org/item/96445 }}$

DOI: https://doi.org/10.1111/j.1469-7998.1863.tb00392.x

Permalink: https://www.biodiversitylibrary.org/partpdf/73996

\section{Holding Institution}

Natural History Museum Library, London

\section{Sponsored by}

Natural History Museum Library, London

\section{Copyright \& Reuse}

Copyright Status: Public domain. The BHL considers that this work is no longer under copyright protection.

This document was created from content at the Biodiversity Heritage Library, the world's largest open access digital library for biodiversity literature and archives. Visit BHL at https://www.biodiversitylibrary.org. 